\title{
Resistance Potential of Chrysoperla carnea (Stephens) to Insecticides Used Against Sucking Complex of Cotton
}

\author{
Mubasshir Sohail ${ }^{1,2, ~ *, ~ M u h a m a d ~ H a i d e r ~ N a s a r ~}{ }^{3}$, Raza Muhammad ${ }^{1}$, Qadeer Ahmed Soomro ${ }^{1}$, \\ Muhammad Usman Asif ${ }^{1}$, Jan Muhammad Maari ${ }^{3}$ \\ ${ }^{1}$ Plant Protection Division, Nuclear Institute of Agriculture, Tando Jam, Pakistan \\ ${ }^{2}$ Department of Entomology, University College of Agriculture, University of Sargodha, Sargodha, Pakistan \\ ${ }^{3}$ Department of Plant Protection, Sindh Agriculture University, Tando Jam, Pakistan
}

Email address:

mubasshirsohailroy@gmail.com (M. Sohail)

*Corresponding author

\section{To cite this article:}

Mubasshir Sohail, Muhamad Haider Nasar, Raza Muhammad Qadeer Ahmed Soomro, Muhammad Usman Asif, Jan Muhammad Maari. Resistance Potential of Chrysoperla carnea (Stephens) to Insecticides Used Against Sucking Complex of Cotton. International Journal of Ecotoxicology and Ecobiology. Vol. 4, No. 1, 2019, pp. 1-7. doi: 10.11648/j.ijee.20190401.11

Received: November 30, 2018; Accepted: December 17, 2018; Published: March 5, 2019

\begin{abstract}
The reported high loss mortality rate of green lacewing, (Chrysoperla carnea) have been attributed to diverse factors including unattended use of insecticides. Since chemical control is one of a significant practice to manage insect pest in cotton. However, this kind of practice may impair the natural control provided by generalist predator C. carnea. Although, natural control adoption is limited in crops, area and season due to wide-spread use of insecticides but presence of resistance potential in C. carnea may improve the design of solid IPM strategies. Herein, we aimed to assess the toxicity of four insecticides to two strains of $C$. carnea (viz. laboratory reared and field collected adults) and to evaluate their resistance potential by calculating their resistance ratio. $\mathrm{LC}_{50}$ was calculated at $24 \mathrm{~h}$ following topical application administered when the adults were 3 days old. Control adult mortalities were less than $10 \%$ at $24 \mathrm{~h}$. The $\mathrm{LC}_{50}$ values $\left(\mu 1 \mathrm{~mL}^{-1}\right)$ for laboratory reared strains of each tested insecticide were: acetamiprid, 0.0064; bifenthrin, 3.75; chlorpyrifos, 0.067; and profenofos, 0.052. The $\mathrm{LC}_{50}$ values for field collected strains were 0.096 (acetamiprid), 34.8 (bifenthrin), 0.21 (chlorpyrifos) and 0.44 (profenofos). The toxicity of the test insecticide to $C$. carnea from more to least toxic was acetamiprid $>$ profenofos $>$ chlorpyrifos $>$ bifenthrin. Field collected strain possessed 15 (acetamiprid)-, 9.28 (bifenthrin)-, 3.13 (chlorpyrifos)-, and 8.5 (profenofos)-fold more resistance than the susceptible population. These results are pretty worthwhile for integration of $C$. carnea in IPM programs, impairing with insecticides.
\end{abstract}

Keywords: Green Lacewing, Chrysoperla, Resistance Potential, Insecticides, Toxicity

\section{Introduction}

Conservation natural control, in which beneficial fauna are preserved in the agroecosystem, has been considered as an element progressively important in Integrated Pest Management (IPM) programs [1]. It is the only way to maintain and enhance the survival, reproduction, and efficiency of natural enemies, which are directly involved in regulating populations of various agricultural and forest insect pests. Approaches to the conservation of these natural enemies involve the adoption of practices that benefit them, as well as avoidance of practices that could be harmful [2].
Among natural enemies in Asia, a large number of predators can control insect pest in cotton (Gossypium hirsutum L.) such as Coccinellids, Chrysopids, Anthocoris and Spiders [3]. The green lacewing Chrysoperla carnea (Stephen) (Neuroptera: Chrysopidae) stand out as important predator, especially of the sucking complex of cotton [4]. The larvae of $C$. carnea are generalist predator which can also feed on eggs and small larvae of lepidoptera, scales, aphids, psilids and whiteflies [5]. It is worth mentioning that the use of chrysopids in IPM as increased since last few years, 
mainly due to its adaptability, voracity and relative wide tolerance to several insecticides $[6,7]$.

Regardless of advances in insect management technologies, use of insecticides is still a common practice worldwide for the control of various insect pest populations [8]. However, insecticides have been also reported with numerous demerits, such as the emergence of secondary pest populations, resurgence of various pests, producing resistant pest populations, and lethal effects on the natural enemies cohabiting in agroecosystem $[7,9]$. Based on the importance of $C$. carnea eggs and pupae, tolerance to insecticides may play a vital role to eliminate the pests which are usually escaped from chemical control [1]. One of the main agenda of IPM is the combination of selective insecticides with natural enemies. Therefore, the evaluation of insecticidal effects on biological control agents is essential prior to the execution of and IPM program [10, 11]. Theoretically, few studies have been addressed that all developmental stages (eggs, larva, pupa, and adult) of green lacewing are susceptible to insecticides, the exposure may lead to lethal and sub-lethal effects $[7,12]$. Most of the studies highlighted lethal and sub-lethal effects of selective insecticides on larvae and adult lacewing [13-15], and some have focused on eggs and pupae that can be considered more tolerant to insecticides [6, 16, 17].

Insecticide resistance in insect pest has adverse consequences but can be used as a positive attribute for biological control agents as a valuable tool in pest management [18]. Most studies on insecticide resistance in biological control agents try to establish the degree of compatibility using only a population, without considering the natural variation in susceptibility of insecticides. However, variation in response to insecticides among the populations of natural enemies is similar to the response in any other insect pest [19]. So, the knowledge of the potential resistance of natural enemies to insecticides may improve strong IPM approaches.

In the present study, the toxicity of insecticides used in cotton cultivation, commonly against sucking complex were investigated on laboratory reared and field collected strain of C.carnea. The information generated through the present study would be a better understanding of insecticide resistance in natural enemies that will guide us to improve the integration of chemical and biological tools in IPM programs.

\section{Materials and Methods}

\subsection{Insect Collection}

C. carnea adults (about 2700) were collected from different fields (cotton, brassica etc) of Tandojam (location: $25.4203^{\circ} \mathrm{N}, 68.5445^{\circ} \mathrm{E}$ ) in the year 2017 by using specialized LED-based light traps which can easily target lacewing trichromatic vision [20]. Each trap was equipped with four strips (each strip contain 12 LEDs) able to emit UV the first (250 mcd and $395 \mathrm{~nm}$ wavelength) and flashing white light second (11,000 mcd and $455 \mathrm{~nm}$ wavelength). Traps were provided with a $12 \mathrm{~V}$ battery for $7 \mathrm{Ah}$ and left the switch on from $7 \mathrm{pm}$ to $10 \mathrm{pm}$. Capturing was also done by hand sweeping net around the traps.

\subsection{Insect Rearing}

Collected adults (field strain) and laboratory reared (G273) strains were kept in rearing cage $(24.5 \times 24.5 \times 24.5$ $\mathrm{cm})$ provisioned with an artificial diet consisting sugar, honey, yeast and distilled water $(2: 1: 1: 2)$ in the laboratory [21]. Black linen cloth was provided at the top of cages for egg laying and removed on each alternate day to harvest the eggs. The eggs were placed in black cloth (cover cloth) and fed on frozen Angoumois grain moth (Sitotroga cereallela Olivier) eggs [9]. After hatching (48 - $60 \mathrm{hrs}$ ), individual $1^{\text {st }}$ instar larvae were sealed in 2 inches polypropylene transparent straw with three pin aeration holes to avoid the cannibalism. The culture was maintained in the Biological Control Laboratory, Nuclear Institute of Agriculture at $25 \pm 1{ }^{\circ} \mathrm{C}$ and $60 \pm 5 \% \mathrm{RH}$ and 15:9 (L:D) till pupation. Tubes were cut out and small open pieces of the tube along with pupae and placed on glass petri plates $(9 \mathrm{~cm}$ diameter and $1.5 \mathrm{~cm}$ height) for emergence. The population of $C$. carnea reared for 10 years in the mentioned laboratory without exposure, was designated as Susceptible strain [22, 23].

\subsection{Insecticides Formulation}

Commercial insecticides were used for bioassays. The four insecticides (Acetamiprid: Acelan ${ }^{\circledR} 20$ SL, FMC, expiry date March 2019; Chlorpyrifos: Cordelia ${ }^{\circledR} 40$ EC, FMC, expiry date July 2018; Bifenthrin: Talstar ${ }^{\circledR} 10$ EC, FMC, expiry date March 2019; and Profenofos: Curacron ${ }^{\circledR} 50$ EC, Syngenta, expiry date November 2018) used under study were purchased their registered dealers. Firstly determined the correction factor (CF) to have a $100 \%$ stock solution. Pilot studies were conducted to determine the suitable concentration range to use for each insecticide. On these basis, following concentrations were evaluated to determine the $\mathrm{LC}_{50}$ for susceptible strain: Acetamprid: 0.001, 0.002, $0.005,0.01,0.02,0.05$ and $0.1 \mu \mathrm{mL}^{-1}$; Bifenthrin: 0.9, 1.2, $1.5,2,5$ and $10 \mu \mathrm{mL}^{-1}$; Chlorpyrifos: $0.0075,0.01,0.02$, $0.05,0.1,0.15,0.2$ and $0.5 \mu 1 \mathrm{~mL}^{-1}$; and Profenofos: 0.0075, $0.01,0.02,0.05,0.07,0.08,0.1$ and $0.2 \mu \mathrm{l} \mathrm{mL}^{-1}$. The following concentrations were used to determine $\mathrm{LC}_{50}$ for field strain: Acetamiprid: 0.001, 0.002, 0.005, 0.01, 0.05, 0.1, 0.2 and $0.4 \mu \mathrm{mL}^{-1}$; Bifenthrin: 5, 10, 15, 30, 50, 60 and 70 $\mu 1 \mathrm{~mL}^{-1}$; Chlorpyrifos: 0.01, 0.02, 0.03, 0.06, 0.12, 0.24, 0.48 and $0.96 \mu \mathrm{mL}^{-1}$; and Profenofos: $0.01,0.03,0.05,0.1,0.25$, $0.5,1$ and $1.5 \mu \mathrm{mL}^{-1}$. All insecticides were dissolved in acetone to prepare stock solution.

\subsection{Concentration Response Bioassay}

Concentration response bioassays of insecticides were conducted for $48-60$ hours old $C$. carnea adults as described previously [21]. All above mentioned 
concentrations were made as serial dilutions, each concentration was replicated three times for each bioassay. $1 \mu 1$ of each serial concentration was applied on the thorax of each individual adult with Arnold Micro-applicator (type LV.65. Burkard, UK) as described by Mansoor et al., [21]. Each replication contained thirty adults, and a total of ninety adults was exposed to each concentration of insecticide. Treated adults were provided with artificial diet as described earlier. Mortality was assessed $24 \mathrm{~h}$ after exposure to insecticides. Mortality was determined by viewing the adult's movement and activity of antennae by touching.

\subsection{Statistical Analysis}

Mortality ratio of $C$. carnea was corrected using solvent control mortality via the Abbott formula. Concentrationresponse data were analyzed with analytical software POLO [24]. The $\log$ concentration-response curves allowed determination of $\mathrm{LC}_{50}, \mathrm{LC}_{90}$, Chi-square $\left(\chi^{2}\right)$ and slopes $\pm \mathrm{SE}$ values for the adult Bioassay according to probit analysis [25]. The $95 \%$ confidence limits for the range of $\mathrm{LC}_{50}$ values were calculated by least-regression analyses against the logarithm of insecticide concentration. The lethal concentration values were considered similar if their $95 \%$ confidence limits overlapped [26].

\section{Results}

Solvent control mortality was lower than $10 \%$ at $24 \mathrm{~h}$ after treatment. The toxicity of insecticides tested are reported in Table 1 and 2 and have shown graphically in Figure 1 and 2. The $\mathrm{LC}_{50}$ values of acetamiprid, bifenthrin, chlorpyrifos, and profenofos for laboratory reared susceptible stain of $C$. carnea were $0.0064,3.75,0.067$ and $0.052 \mu 1 \mathrm{~mL}^{-1}$, and LC50 values for field collected strains were 0.096, 34.8, 0.21 and 0.44 , respectively. Toxicity of the test insecticides to $C$. carnea adults form most to least toxic was acetamiprid $>$ profenofos $>$ chlorpyrifos $>$ bifenthrin. The $95 \%$ confidence intervals for chlorpyrifos and profenofos were overlapped, suggesting no significant difference in the toxicities of these two insecticides to $C$. carnea adults.

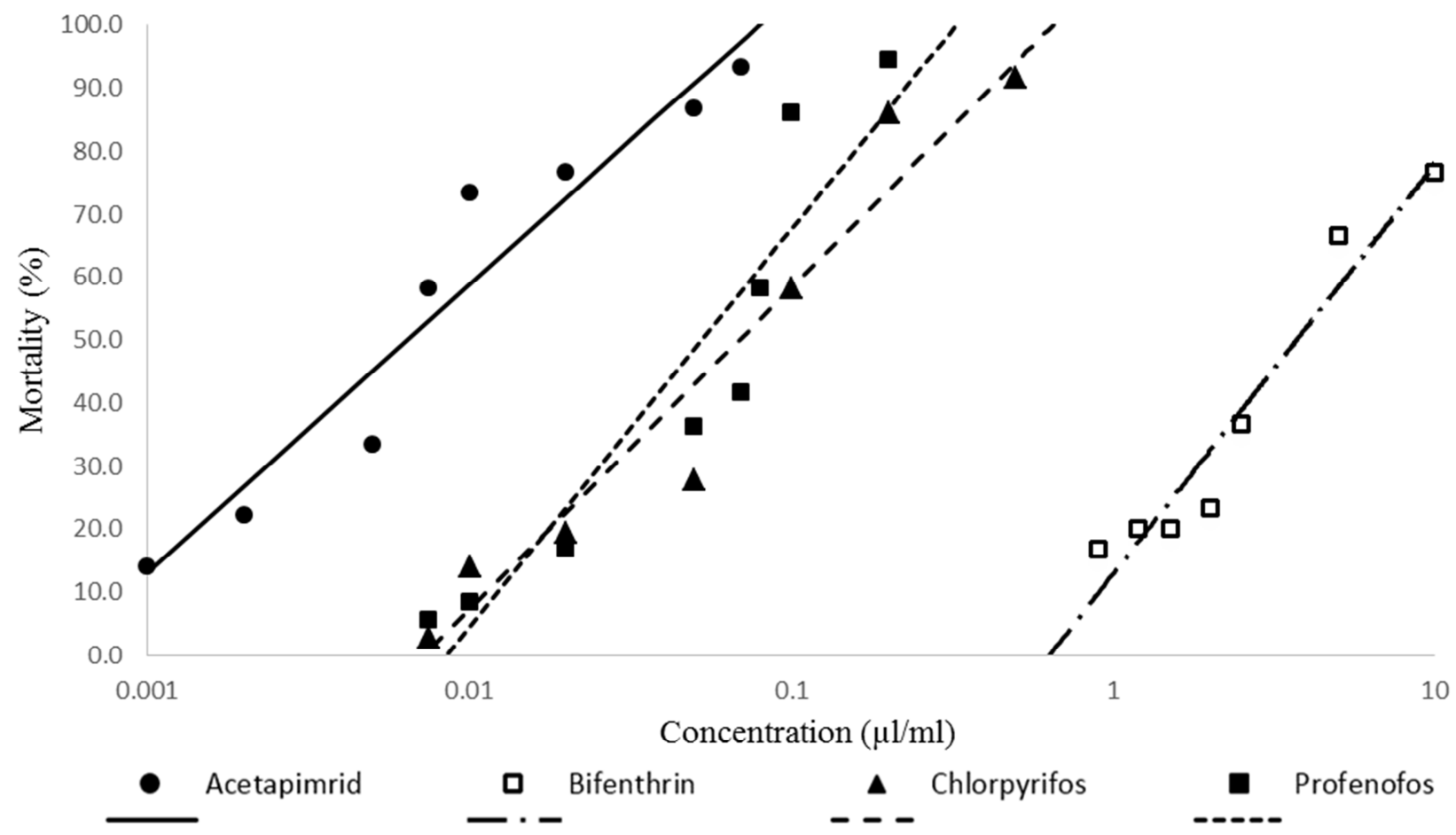

Figure 1. The mortality response of susceptible (G-273) strain of $C$. carnea after exposure to Acetamiprid, Bifenthrin, Chlorpyrifos, and Profenofos. The concentration response line of each population was drawn using a probit linear model $y=\alpha x+\beta$ in which $\alpha$ and $\beta$ are the slope and intercept, respectively. $x$ is the log-transformation concentration $(\mu \mathrm{l} / \mathrm{ml})$ and $y$ is the percent mortality.

Table 1. Toxicity of insecticides to the susceptible strain (G-273) of C. carnea.

\begin{tabular}{|c|c|c|c|c|c|c|}
\hline \multirow{2}{*}{ Insecticides } & \multirow{2}{*}{$\mathrm{LC}_{50}(95 \% \mathrm{CI})\left|\mu \mathrm{I} \mathrm{mL}^{-1}\right|$} & \multirow{2}{*}{$\mathrm{LC}_{90}(95 \% \mathrm{CI})\left|\mu \mathrm{l} \mathrm{mL} \mathrm{L}^{-1}\right|$} & \multicolumn{4}{|c|}{ The fit of probit line } \\
\hline & & & Slope $( \pm$ SE) & $d f$ & $\mathbf{N}^{\mathbf{a}}$ & $\chi^{2}$ \\
\hline Acetamiprid & $0.0064(0.004 \pm 0.011)$ & $0.059(0.035 \pm 0.1)$ & $1.34( \pm 0.12)$ & 6 & 750 & 0.98 \\
\hline Bifenthrin & $3.75(2.49 \pm 5.64)$ & $19.39(12.88 \pm 29.62)$ & $1.81( \pm 0.09)$ & 5 & 660 & 0.97 \\
\hline Chlorpyrifos & $0.067(0.04 \pm 0.11)$ & $0.38(0.25 \pm 0.59)$ & $1.75( \pm 0.1)$ & 6 & 750 & 0.78 \\
\hline Profenofos & $0.052(0.04 \pm 0.07)$ & $0.22(0.15 \pm 0.31)$ & $2.14( \pm 0.08)$ & 6 & 750 & 0.87 \\
\hline
\end{tabular}

${ }^{a}$ Number of C. carnea individuals used in bioassay and control. 
Table 2. Toxicity of insecticides to the field collected strain of C. carnea.

\begin{tabular}{|c|c|c|c|c|c|c|c|}
\hline \multirow{2}{*}{ Insecticides } & \multirow{2}{*}{$\mathbf{L C}_{50}(95 \% \mathrm{CI})\left|\mu \mathrm{I} \mathrm{mL}^{-1}\right|$} & \multirow{2}{*}{$\mathrm{LC}_{90}(95 \% \mathrm{CI})\left|\mu \mathrm{I} \mathrm{mL}^{-1}\right|$} & \multicolumn{5}{|c|}{ The fit of probit line } \\
\hline & & & Slope $( \pm$ SE) & $d f$ & $\mathrm{~N}^{\mathrm{a}}$ & $\chi^{2}$ & $\mathbf{R R}^{\mathrm{b}}$ \\
\hline Acetamiprid & $0.096(0.04 \pm 0.31)$ & $18.4(5.72 \pm 59.31)$ & $0.58( \pm 0.3)$ & 6 & 510 & 0.79 & 15 \\
\hline Bifenthrin & $34.8(25.4 \pm 49.9)$ & $130.1(92.7 \pm 182.2)$ & $2.32( \pm 0.08)$ & 5 & 450 & 0.96 & 9.28 \\
\hline Chlorpyrifos & $0.21(0.11 \pm 0.36)$ & $2.28(1.27 \pm 4.09)$ & $1.24( \pm 0.1)$ & 6 & 510 & 0.97 & 3.13 \\
\hline Profenofos & $0.44(0.24 \pm 0.81)$ & $4.79(2.64 \pm 8.68)$ & $1.25( \pm 0.1)$ & 6 & 510 & 0.98 & 8.5 \\
\hline
\end{tabular}

${ }^{a}$ Number of $C$. carnea individuals used in bioassay and control.

${ }^{b}$ Resistance ratio, $L C_{50}$ of the field strains / $L C_{50}$ of susceptible (G-273) strains

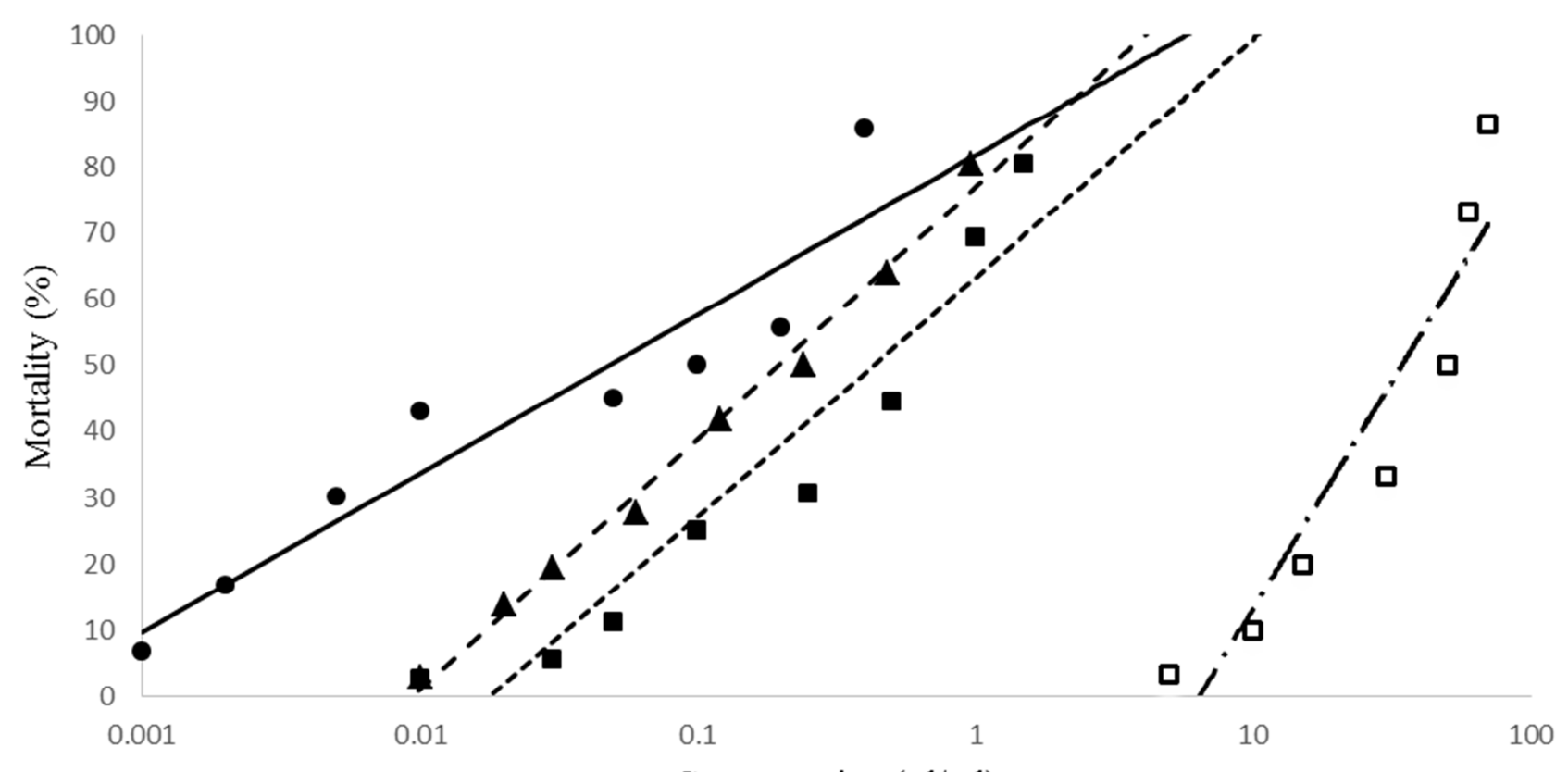

Concentration $(\mu 1 / \mathrm{ml})$

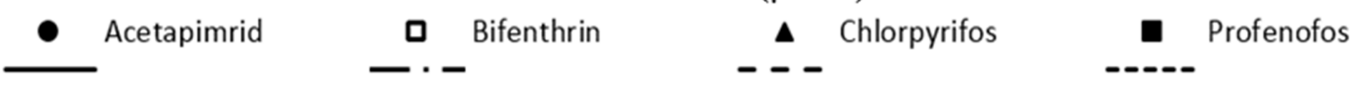

Figure 2. The mortality response of field collected strains of C. carnea after exposure to Acetamiprid, Bifenthrin, Chlorpyrifos, and Profenofos. The concentration response line of each population was drawn using a probit linear model $y=\alpha x+\beta$ in which $\alpha$ and $\beta$ are the slope and intercept, respectively. $x$ is the log-transformation concentration $(\mu \mathrm{l} / \mathrm{ml})$ and $y$ is the percent mortality.

\section{Discussion}

The role of a generalist predator, $C$. carnea is obvious and well known, however, their presence in the field is dependent upon the lack of disruption due to different insecticides [21]. Therefore, there is a need to study the evolution of insecticides resistance in C. carnae, which are regularly used for the management of various insect pests. The in-vitro studies demonstrated its worth for evaluating the toxicity of insecticides on adults $C$. carnea by providing quantitative data with high accuracy and reproducibility and avoiding environmental variation [27]. The techniques discussed herein demonstrated the effectiveness of a reliable acute toxicity assay for laboratory reared adults and their difference to the field collected strain. The $\mathrm{LC}_{50}$ values of acetamiprid, bifenthrin, chlorpyrifos, and profenofos for laboratory reared susceptible strain and field collected strains of $C$. carnea were evaluated.

Maximum toxicity $\left[\left(\mathrm{LD}_{50}=0.0064(0.004 \pm 0.011)\right]\right.$ was observed in the case of acetamiprid, belong to a new, widely used class of insecticide, the neonicotinoids. With identical structure to nicotine, they also share agonist activity at ionotropic or nicotinic acetylcholine receptors (nAChRs) [28, 29]. Its toxicity against many insect fauna related to cotton and ornamental plants are well established [30]. Its resistance has previously been reported in C. carnea at different locations (Muzaffargarh; $30.0703^{\circ} \mathrm{N}, 71.1933^{\circ} \mathrm{E}$ ) in Pakistan.

The toxicity test in the present study evidently proved the toxicity of organophosphate insecticides (i.e. profenofos and chlorpyrifos) to the $C$. carnea adults. Non-significant difference was found in their toxicity to $C$. carnea. Percent mortality was increased with increase in the concentration of these insecticides. Like other organophosphate insecticides, chlorpyrifos and profenofos kill targeted insects by inhibiting the action of acetylcholinesterase. It is usually responsible for degradation of excitatory neurotransmitter, acetylcholine, thereby termination of nerve impulse transmission at cholinergic synapses [31], which is critical to the functioning of the insect nervous system [29, 32]. Once this enzyme is inhibited, acetylcholine builds up and insect expire from overstimulation of their nervous system [33].

However, among the test insecticides, bifenthrin showed the least toxicity $\left[\mathrm{LC}_{50}=3.75(2.49 \pm 5.64)\right]$ to $C$. carnea 
adults. It is also an insecticide that has been using frequently by the cotton growers of Pakistan against insect pests, also affects natural enemies [34]. The basic mechanism of bifenthrin involves binding to voltage-gated sodium channels, important sites for neurotoxic action and modifying their kinetics, causing disrupt the normal functioning of nerves $[35,36]$.

The results of our studies, where we applied insecticides directly onto the field collected strain of $C$. carnea suggested the resistance potential is present in their adults. Resistance ratio depicting their folds of resistance to particular insecticide. Field collected population has 15 (acetamiprid)-, 9.28 (bifenthrin)-, 3.13 (chlorpyrifos)-, and 8.5 (profenofos)fold more resistance than the susceptible population. Although, resistance in insect pest outnumber resistance in the natural enemies especially the predators was more than twenty to one. This attribute most probably indicates limited devotions to resistance in natural enemies as well as biological difference among natural enemies and pests [18]. It is well documented that the natural enemies develop resistance less readily as detoxification enzymes level is lower the predators than in pests or because they suffered due to food limitation insecticide that severely lessens their host or prey [37].

Insecticide resistance mainly credited due to either or all of these mechanisms viz. metabolic, decrease penetration, target site insensitivity and behavioral resistance [38]. Decreased penetration and target site insensitivity are less common and contribute little for resistance in many cases [39]. Enhanced metabolic resistance includes esterases, cytochrome $\mathrm{P} 450$ mono-oxygenase and glutathione enzyme complex [38]. In the present study, resistance to the bifenthrin, suggesting the involvement of esterases and mono-oxygenases in the $C$. carnea $[21,40]$. Previously resistance to pyrethroids mediated by mono-oxygenases has been reported in C. carnea [21, 41]. While, organophosphate are attacked by about three enzyme systems, the polysubstrate monooxygenases (PSMOs), carboxylesterases with phosphatase activity and glutathione transferases [31]. The latter two invariably detoxify the organophosphate by splitting off alkyl or other substituents. However, the performance of cytochrome P450 can result in activation of phosphorothioates if the $\mathrm{P}=\mathrm{S}$ is changed to $\mathrm{P}=\mathrm{O}$ by oxidative desulfuration, or in detoxification, the carbon of one of the small alkyl substituents is oxidized [42, 43]. Likewise, P450 mediated detoxification probably acts a substantial part in neonicotinoid (imidachloprid) resistance in most of the insects but there would be some secondary mechanism involved [44].

\section{Conclusion}

C. carnea population possesses the resistance potential against the test insecticides and could be used as a positive trait for the improvement in their survival opportunities in the field. This potential may lead C. carnea to higher predation rates and fitness advantages as Mansoor et al., [21] reported previously. However, the outcome of our studies would be a better understanding of insecticide resistance in C. carnea, ultimately will allow us to improve the integration of biological and chemical tools simultaneously in IPM programs.

\section{Acknowledgements}

The authors acknowledge the support staff members of biocontrol labs for collection of that huge amount of required insects for field. We are also grateful to other individuals (Munawar Ali, and Muhammad Naeem) for their assistance during the study.

\section{References}

[1] Reddy, P. P., 2016. Selective pesticides in IPM, in Sustainable Crop Protection under Protected Cultivation. Springer: New York, USA. pp. 121-131.

[2] Jonsson, M., Wratten, S. D., Landis, D. A., and Gurr, G. M. 2008. Recent advances in conservation biological control of arthropods by arthropods. Biological Control. 45 (2): pp. 172175 .

[3] Ali, A., Desneux, N., Lu, Y., Liu, B., and Wu, K. 2016. Characterization of the natural enemy community attacking cotton aphid in the Bt cotton ecosystem in Northern China. Scientific Reports. 6: pp. 24273.

[4] Ruberson, J. R., Thompson, M. D., and Roberts, P. M. 2003. Pesticide effects on insect natural enemies of cotton pests. Cotton Research Extension Report: pp. 124-132.

[5] Lavagnini, T., Morales, A., and Freitas, S. 2015. Population genetics of Chrysoperla externa (Neuroptera: Chrysopidae) and implications for biological control. Brazilian Journal of Biology. 75 (4): pp. 878-885.

[6] Vargas Castilhos, R., Dionei Grützmacher, A., Baier Siqueira, P. R., de Moraes, Í. L., and Gauer, C. J. 2014. Seletividade de agrotóxicos utilizados em pessegueiro sobre ovos e pupas do predador Chrysoperla externa. Ciência Rural. 44 (11).

[7] Rugno, G. R., Zanardi, O. Z., and Yamamoto, P. T. 2015. Are the pupae and eggs of the lacewing Ceraeochrysa cubana (Neuroptera: Chrysopidae) tolerant to insecticides? Journal of Economic Entomology. 108 (6): pp. 2630-2639.

[8] Ndakidemi, B., Mtei, K., and Ndakidemi, P. A. 2016. Impacts of synthetic and botanical pesticides on beneficial insects. Agricultural Sciences. 7 (06): pp. 364.

[9] Pasini, R. A., Grützmacher, A. D., de Bastos Pazini, J., de Armas, F. S., Bueno, F. A., and Pires, S. N. 2018. Side effects of insecticides used in wheat crop on eggs and pupae of Chrysoperla externa and Eriopis connexa. Phytoparasitica. 46 (1): pp. 115-125.

[10] Desneux, N., Decourtye, A., and Delpuech, J.-M. 2007. The sublethal effects of pesticides on beneficial arthropods. Annual Review of Entomolology. 52: pp. 81-106.

[11] Fogel, M. N., Schneider, M. I., Desneux, N., González, B., and Ronco, A. E. 2013. Impact of the neonicotinoid acetamiprid on immature stages of the predator Eriopis connexa (Coleoptera: Coccinellidae). Ecotoxicology. 22 (6): pp. 1063-1071. 
[12] Stark, J. D., Vargas, R., and Banks, J. E. 2007. Incorporating ecologically relevant measures of pesticide effect for estimating the compatibility of pesticides and biocontrol agents. Journal of Economic Entomology. 100 (4): pp. 10271032 .

[13] Moura, A. P., Carvalho, G. A., Moscardini, V. F., Lasmar, O., Rezende, D. T., and Marques, M. C. 2010. Selectivity of pesticides used in integrated apple production to the lacewing, Chrysoperla externa. Journal of Insect Science. 10 (1): pp. 121.

[14] Vilela, M., Andrade Carvalho, G., Freire Carvalho, C., Alvarenga Vilas Boas, M., and Santos Leite, M. I. 2010. Seletividade de acaricidas utilizados em cafeeiro para larvas de crisopídeos. Revista Ceres. 57 (5).

[15] Castilhos, R. V., Grützmacher, A. D., Nava, D. E., Zotti, M. J., Siqueira, P. R. B., and Spagnol, D. 2013. Selectivity of pesticides used in peach orchards on the larval stage of the predator Chrysoperla externa (Hagen)(Neuroptera: Chrysopidae). Semina: Ciências Agrárias, Londrina. 34 (6sup1): pp. 3585-3596.

[16] Silva, R. A., Andrade Carvalho, G., Freire Carvalho, C., Rebelles Reis, P., Souza, B., and Andrade Rezende Pereira, A. M. 2006. Ação de produtos fitossanitários utilizados em cafeeiros sobre pupas e adultos de Chrysoperla externa (Hagen, 1861)(Neuroptera: Chrysopidae). Ciencia Rural. 36 (1).

[17] de Fátima T, A., Andrade, C., Costa, L. V., and Fonseca, M. 2013. Selectivity of seven insecticides against pupae and adults of Chrysoperla externa (Neuroptera: Chrysopidae). Revista Colombiana de Entomología. 39 (1): pp. 34-39.

[18] Bielza, P., 2016. Insecticide Resistance in Natural Enemies, in Advances in Insect Control and Resistance Management. Springer: New York, USA. pp. 313-329.

[19] Hoy, M. A., 1990. Pesticide resistance in arthropod natural enemies: variability and selection responses, in Pesticide resistance in arthropods. Springer. pp. 203-236.

[20] Gaglio, G., Napoli, E., Falsone, L., Giannetto, S., and Brianti, E. 2017. Field evaluation of a new light trap for phlebotomine sand flies. Acta Tropica. 174: pp. 114-117.

[21] Mansoor, M. M., Raza, A. B. M., Abbas, N., Aqueel, M. A., and Afzal, M. 2017. Resistance of green lacewing, Chrysoperla carnea Stephens to nitenpyram: Cross-resistance patterns, mechanism, stability, and realized heritability. Pesticide Biochemistry and Physiology. 135: pp. 59-63.

[22] Mansoor, M. M., Abbas, N., Shad, S. A., Pathan, A. K., and Razaq, M. 2013. Increased fitness and realized heritability in emamectin benzoate-resistant Chrysoperla carnea (Neuroptera: Chrysopidae). Ecotoxicology. 22 (8): pp. 12321240.

[23] Abbas, N., Mansoor, M. M., Shad, S. A., Pathan, A. K., Razaq, M., and Zulfiqar, M. 2014. Fitness cost and realized heritability of resistance to spinosad in Chrysoperla carnea (Neuroptera: Chrysopidae). Bulletin of Entomological Research. 104 (6): pp. 707-715.

[24] Robertson, J. L., Jones, M. M., Olguin, E., and Alberts, B., 2017 Bioassays with arthropods. Taylor and Francis Group, Florida, USA: CRC press. 998.

[25] Finney, D. J., 1971 Probit Analysis. 3rd ed., Cambridge, UK:
Cambridge University Press. 358.

[26] Shrestha, G., Enkegaard, A., and Giray, T. 2013. The green lacewing, Chrysoperla carnea: preference between lettuce aphids, Nasonovia ribisnigri, and western flower thrips, Frankliniella occidentalis. Journal of Insect Science. 13 (1).

[27] Vogt, H., Bigler, F., Brown, K., Candolfi, M., Kemmeter, F., Kühner, C., Moll, M., Travis, A., Ufer, A., and Viñuela, E. 2000. Laboratory method to test effects of plant protection products on larvae of Chrysoperla carnea (Neuroptera: Chrysopidae). Ecotoxicology: pp. 27-44.

[28] Kimura-Kuroda, J., Komuta, Y., Kuroda, Y., Hayashi, M., and Kawano, H. 2012. Nicotine-like effects of the neonicotinoid insecticides acetamiprid and imidacloprid on Cerebellar neurons from neonatal rats. PLoS One. 7 (2): pp. e32432.

[29] Firestone, J. and Keifer, M. C. Neurotoxicity of Pesticides. in Proceedings from the Medical Workshop on Pesticide-Related Illnesses from the International Conferen. 2017. Routledge.

[30] Basit, M., Sayyed, A. H., Saleem, M. A., and Saeed, S. 2011. Cross-resistance, inheritance and stability of resistance to acetamiprid in cotton whitefly, Bemisia tabaci Genn (Hemiptera: Aleyrodidae). Crop Protection. 30 (6): pp. 705712.

[31] Siegfried, B. D. and Scharf, M. E., 2001. Mechanisms of organophosphate resistance in insects, in Biochemical sites of insecticide action and resistance. Springer: New York, USA. pp. 269-291.

[32] Lapied, B. 2017. Insecticide mode of action: From insect to mammalian toxicity. Current Medicinal Chemistry. 24 (27): pp. 2910-2911.

[33] Kishk, A., Hijaz, F., Anber, H. A., AbdEl-Raof, T. K., ElSherbeni, A.-H. D., Hamed, S., and Killiny, N. 2017. RNA interference of acetylcholinesterase in the Asian citrus psyllid, Diaphorina citri, increases its susceptibility to carbamate and organophosphate insecticides. Pesticide Biochemistry and Physiology. 143: pp. 81-89.

[34] Haider, I., Suhail, A., and Aziz, A. 2017. Toxicity of some insecticides against cotton jassid (Amrasca devastans dist.) and its predator (Chrysoperla carnea steph.). Journal of Agricultural Research. 55 (2).

[35] Abreu-Villaça, Y. and Levin, E. D., 2018. Developmental Neurobehavioral Neurotoxicity of Insecticides: Handbook of Developmental Neurotoxicology. Elsevier: New York, USA. pp. 453-466.

[36] Malik, J. K., Aggarwal, M., Kalpana, S., and Gupta, R. C., 2017. Chlorinated hydrocarbons and pyrethrins/pyrethroids, in Reproductive and Developmental Toxicology (Second Edition). Elsevier. pp. 633-655.

[37] Panini, M., Manicardi, G., Moores, G., and Mazzoni, E. 2016. An overview of the main pathways of metabolic resistance in insects. Invertebrate Survival Journal. 13: pp. 326-335.

[38] Muthusamy, R., Suganya, R., Gowri, M., and Shivakumar, M. 2013. Biochemical mechanisms of organophosphate and pyrethroid resistance in red hairy caterpillar Amsacta albistriga (Lepidoptera: Arctiidae). Journal of the Saudi Society of Agricultural Sciences. 12 (1): pp. 47-52.

[39] Ahmad, M. and McCaffery, A. R. 1999. Penetration and metabolism of trans-cypermethrin in a susceptible and a pyrethroid-resistant strain of Helicoverpa armigera. Pesticide Biochemistry and Physiology. 65 (1): pp. 6-14. 
[40] Afzal, M. B. S., Shad, S. A., and Abbas, N. 2015. Genetics, realized heritability and preliminary mechanism of spinosad resistance in Phenacoccus solenopsis Tinsley (Homoptera: Pseudococcidae): an invasive pest from Pakistan. Genetica. 143 (6): pp. 741-749.

[41] Pree, D., Archibald, D., and Morrison, R. 1989. Resistance to insecticides in the common green lacewing Chrysoperla carnea (Neuroptera: Chrysopidae) in southern Ontario. Journal of Economic Entomology. 82 (1): pp. 29-34.

[42] Yang, M., Zhang, J., Zhu, K., Xuan, T., Liu, X., Guo, Y., and Ma, E. 2009. Mechanisms of organophosphate resistance in a field population of oriental migratory locust, Locusta migratoria manilensis (Meyen). Archives of Insect Biochemistry and Physiology. 71 (1): pp. 3-15.

[43] Carvalho, R. A., Omoto, C., Field, L. M., Williamson, M. S., and Bass, C. 2013. Investigating the molecular mechanisms of organophosphate and pyrethroid resistance in the fall armyworm Spodoptera frugiperda. PLoS One. 8 (4): pp. e62268.

[44] Puinean, A. M., Foster, S. P., Oliphant, L., Denholm, I., Field, L. M., Millar, N. S., Williamson, M. S., and Bass, C. 2010. Amplification of a cytochrome P450 gene is associated with resistance to neonicotinoid insecticides in the aphid Myzus persicae. PLOS Genetics. 6 (6): pp. e1000999. 